\title{
ARTYKUŁY
}

Klio. Czasopismo poświęcone dziejom Polski i powszechnym

PL ISSN 1643-8191, t. 48 (1)/2019, s. 41-59

(c) (1) $\Theta$

http://dx.doi.org/10.12775/KLIO.2019.003

KONRAD BOBIATYŃSKI"

\section{Rachunki wojskowe hetmana polnego liteuskiego Michała Kazimierza Radziwiłła ${ }^{* *}$}

\section{Military accounts of the Lithuanian Field Hetman Michał Kazimierz Radziwiłł}

Streszczenie: W artykule tym zostały omówione wydatki wojskowe hetmana polnego litewskiego Michała Kazimierza Radziwiłła z lat 1668-1673 oraz roku 1676. Stanowią one bardzo dobre źródło do analizy struktury budżetu hetmańskiego w Wielkim Księstwie Litewskim w drugiej połowie XVII wieku. Drugą część opracowania stanowi edycja tych źródeł, przechowywanych obecnie w Rosyjskiej Bibliotece Narodowej w Sankt Petersburgu.

Abstract: The article discusses the military expenses of the Lithuanian Field Hetman Michał Kazimierz Radziwiłł in the years 1668-1673 and 1676. It is a good source to

* Instytut Historyczny Uniwersytet Warszawski, Krakowskie Przemieście 26/28, 00-927 Warszawa, k_bob@wp.pl, ORCID: 0000-0002-9832-3048.

** Artykuł powstał w ramach grantu Narodowego Programu Rozwoju Humanistyki nr 11H 13033482 pt. „Akta skarbowe jako źródło do dziejów wojskowości staropolskiej za panowania Wazów (1587-1668)”, realizowanego w latach 2015-2020. 
reconstruct the structure of the budget of Lituanian hetmans in the second half of the XVII century. The second part is the editions of sources - two military accounts of Michat Kazimierz Radziwiłł, from the National Library of Russia in Sankt Petersburg.

Słowa kluczowe: Wielkie Księstwo Litewskie; hetman; wydatki wojskowe

Keywords: Grand Duchy of Lithuania; hetman; military expenses

Tednym z najciekawszych zespołów źródeł do badania historii Rzeczypospolitej Obojga Narodów, które po traktacie ryskim nie powróciły do Polski i do dzisiaj pozostają na terytorium Federacji Rosyjskiej, jest $\mathrm{z}$ pewnością fragment dawnego archiwum Radziwiłłów nieświeskich. Dokumenty te przechowywane są obecnie w Rosyjskiej Bibliotece Narodowej w Sankt Petersburgu, w zbiorze tzw. Avtografów Dubrovskiego (Российская нацииональная библиотека, Автографы Аубровского, dalej RNB, AD, fond 971). Razem z biblioteką Radziwiłłów, liczącą ok. 20 tys. tomów, zostały one wywiezione na wschód w 1772 roku, po zajęciu i złupieniu Nieświeża przez rosyjskiego generała Aleksandra I. Bibikowa ${ }^{1}$.

Wśród tych materiałów niewątpliwie najbogatsza jest spuścizna związana z działalnością polityczną i wojskową hetmana wielkiego oraz wojewody wileńskiego Krzysztofa Radziwiłła (1585-1640). Znacznie mniej obfite są dokumenty jego syna Janusza (1612-1655), jak również bratanka Bogusława (1620-1669), które stanowią jedynie znikomą część zachowanych archiwów tych magnatów ${ }^{2}$. Natomiast wydaje się, iż znacznie większą

${ }^{1}$ R. Jankowski, Burzliwe losy archiwum Radziwittów z Nieświeża od XV w. do 1838 r., „Miscellanea Historico-Archivistica” 2000, t. 11, s. 55-56.

2 Warto zaznaczyć, iż korespondencja J. Radziwiłła z RNB doczekała się naukowej edycji (Listy Janusza Radziwitta z lat 1646-1653, wyd. T. Ciesielski, „Wrocławskie Studia z Historii Wojskowości” 2012, t. 1: Od Grunwaldu do Bzury - bitwy i boje polskie na przestrzeni dziejów, red. J. Jędrysiak, D. Koreś, J. Maroń i K. Widziński, s. 505-523), a w 2019 r. zostanie wydany diariusz kancelaryjny hetmana, którego część (z 1653 r.) również znajduje się w Petersburgu. Kilka dokumentów z archiwum B. Radziwiłła omówił K. Matwijowski (Bogustaw Radziwitt w okresie elekcji $i$ w pierwszych miesiącach rządów Michata Korybuta, [w:] Między Wschodem a Zachodem. Rzeczpospolita XVI-XVIII w. Studia 
wartość dla historyków mają materiały archiwalne innego przedstawiciela tej rodziny - hetmana polnego i podkanclerzego, szwagra Jana III Sobieskiego - Michała Kazimierza Radziwiłła (1635-1680). Nie ulega bowiem wątpliwości, iż znacząco uzupełniają one dosyć skromny zasób źródeł, jakie pozostały po tym dygnitarzu w zbiorach Archiwum Głównego Akt Dawnych w Warszawie i istotnie poszerzają wiedzę na temat niektórych aspektów jego działalności publicznej³.

Niemal cała „petersburska” spuścizna Michała Kazimierza Radziwiłła jest zebrana w kodeksie opatrzonym sygnaturą 125. Znajdujemy tutaj m.in. asekuracje hetmana (k. 108-111, 119, 122, 124, 126), potwierdzające wypłaty żołdu ze skarbu koronnego i litewskiego dla wystawionych przez niego jednostek wojskowych podczas potopu szwedzkiego (1655-1660), jak również wojny z Państwem Moskiewskim (1654-1667)4 ${ }^{4}$ Ciekawe materiały skarbowe zachowały się również dla okresu konfliktu z Portą Ottomańską (1672-1676) - w tym przypadku są to kapitulacje zawierane z rekrutowanymi przez Radziwiłła oficerami (k. 162), a przede wszystkim asygnacje hetmana, nakazujące przekazanie środków pieniężnych jednostkom zaciąganym przed rozpoczęciem kampanii przeciwko Turkom i ich

ofiarowane Zbigniewowi Wojcikowi w siedemdziesiata rocznicę urodzin, red. T. ChynczewskaHennel et al., Warszawa 1993, s. 151-156; idem, Jeszcze o roli Bogustawa Radziwitta w trakcie elekcji Michata Korybuta Wiśniowieckiego, [w:] Między wielka polityka a szlacheckim partykularzem. Studia z dziejów nowożytnej Polski i Europy: ku czci Profesora Jacka Staszewskiego, red. K. Wajda et al., Toruń 1993, s. 225-231; idem, Listy z ostatnich lat życia Bogustawa Radziwitta, [w:] Między Zachodem a Wschodem. Studia ku czci Profesora Jacka Staszewskiego, t. 2, red. J. Dumanowski, B. Dybaś, K. Mikulski, J. Poraziński i S. Roszak, Toruń 2003, s. 403-408.

${ }^{3} \mathrm{Na}$ temat wojskowych aspektów kariery Radziwiłła najobszerniej piszą: A. Rachuba, Doświadczenie wojskowe hetmana Michata Kazimierza Radziwitta (1635-1680), [w:] Radziwittowie w stużbie Marsa, red. M. Nagielski i K. Żojdź, Warszawa 2017, s. 221-228; K. Bobiatyński, Michat Kazimierz Radziwitt jako hetman polny litewski (1668-1680), [w:] Radziwittowie w stużbie, s. 229-241; zob. też J. Jaroszuk, Radziwitt Michat Kazimierz, PSB, 1987, t. 30, s. 292-299; M. Nagielski, Michat Kazimierz Radziwitt herbu Trąby (1635-1680), hetman polny, [w:] Poczet hetmanów Rzeczypospolitej. Hetmani litewscy, red. M. Nagielski, Warszawa 2006, s. 179-189.

${ }^{4}$ Rozliczenia jednostek M.K. Radziwiłła ze służby podczas potopu, mające miejsce podczas komisji wojskowo-skarbowych z 1662, 1664 i 1667 r., znajdziemy pod sygnaturą 150 (k. 55-59). 
wasalom jesienią 1674 roku (k. 165-171). Podczas tych działań hetmanowi dane było poprowadzić samodzielnie operację militarną - oblężenie Pawołoczy. Z tego okresu zachował się uniwersał księcia (z 17 marca 1675 roku) do miejscowej załogi kozackiej, stojącego na jej czele pułkownika, jak również mieszczan, wzywający do dobrowolnego poddania się i powrotu pod berło polskiego króla (k. 176). Innym ciekawym dokumentem wojskowym jest instrukcja Radziwiłła dla jego posła (skarbnika mozyrskiego Kazimierza Bielikowicza) na sesję wojskową w Grodnie, wydana w Białej 26 grudnia 1668 roku (k. 144-145).

W kodeksie tym znajduje się również kilkanaście listów adresowanych do Radziwiłła. Wśród nich z pewnością należy wspomnieć o uniwersałach i pismach hetmana wielkiego Pawła Jana Sapiehy, pochodzących z okresu walk z wojskami siedmiogrodzkimi (oblężenie przez Litwinów Brześcia) w lipcu i sierpniu 1657 roku (k. 93-105). Jako wartościowe trzeba ocenić relacje przesyłane z obrad sejmików i innych instytucji samorządu szlacheckiego, których autorami byli głównie sojusznicy polityczni i klienci księcia. Pochodzą one z okresu panowania Michała Korybuta Wiśniowieckiego oraz Jana III Sobieskiego (lata 1672-1675). Wydaje się, iż najciekawsze źródło tego typu to list kasztelana żmudzkiego Stanisława Wincentego Ordy z 2 sierpnia 1672 roku, zawierający szereg kapitalnych informacji na temat przebiegu zorganizowanego przez litewskich regalistów zjazdu generalnego w Wilnie. Celem tego zgromadzenia było zamanifestowanie wierności monarsze w obliczu eskalacji konfliktu wewnętrznego i groźby zamachu stanu, jak również sterroryzowanie litewskiej opozycji, na czele której stał Radziwiłł (k. 154-154v)5.

Do najciekawszych dokumentów z „petersburskich” archiwaliów Michała Kazimierza Radziwiłła zaliczają się z pewnością dwa rachunki przedstawiające wydatki wojskowe hetmana polnego z lat 1668-1673 oraz z okresu kampanii żórawińskiej z 1676 roku.

${ }^{5}$ Autorami innych relacji pisanych dla M.K. Radziwiłła są: starosta żmudzki W.K. Mleczko (Rosienie 30 IV 1672, k. 152), wojski mozyrski S.K. Uniechowski (Nowogródek 27 XII 1672, k. 156), marszałek wiłkomierski Jerzy Zygmunt Dunin Rajecki (Wiłkomierz 4 II 1675, k. 175), podkomorzy brzeski Krzysztof Tyszkiewicz (Brześć 24 VII 1675, k. 177). 
W tym miejscu należy zaznaczyć, iż dopiero od niedawna tego typu źródła cieszą się zwiększonym zainteresowaniem historyków. Ostatnio Marek Wagner przeprowadził dokładną analizę wydatków wojskowych Stanisława Jabłonowskiego z drugiej połowy lat osiemdziesiątych XVII wieku, zwracając uwagę na ich przydatność do badań nie tylko nad zagadnieniami stricte wojskowymi, lecz również nad historią dyplomacji, a nawet problematyką społeczną . Przedmiotem odrębnego studium stały się również sprawozdania finansowe hetmanów koronnych z pierwszej połowy lat pięćdziesiątych tego stulecia (Marcina Kalinowskiego i Stanisława Rewery Po-

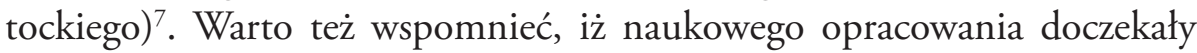
się już niektóre rachunki wojskowe Michała Kazimierza Radziwiłła. Pochodzą one jednak nie z czasu, kiedy sprawował on wysokie urzędy wojskowe, ale z okresu wcześniejszego - z lat 1655-1660, kiedy to książę własnym sumptem utrzymywał garnizon w swojej prywatnej twierdzy w Nieświeżu, skutecznie odpierającej kolejne ataki wojsk carskich ${ }^{8}$. Natomiast wśród źródeł tego typu, które niewątpliwie zasługują na wnikliwe omówienie, należy wymienić przede wszystkim wydatki starszego kolegi Radziwiłła, a przy okazji jego głównego przeciwnika politycznego - hetmana wielkiego Michała Kazimierza Paca, który dwukrotnie - w 1667 i 1670 roku, składał na sejm walny obszerne sprawozdania zawierające szczegółowy wykaz nakładów, jakie poniósł na różne potrzeby wojskowe ${ }^{9}$.

${ }^{6} \mathrm{M}$. Wagner, Wydatki wojskowe hetmana wielkiego koronnego Stanistawa Jabtonowskiego w latach 1685-1689, [w:] Pecunia nervus belli. Z dziejów dyplomacji i stosunków międzynarodowych w XV-XVIII wieku, red. M. Markiewicz, R. Skowron i F. Wolański, Katowice 2016, s. 226-238; idem, „Sprawy motdawskie” w rachunkach hetmana wielkiego koronnego Stanistawa Jabtonowskiego w latach 1685-1689, [w:] Ze wspólnej przesztości. Studia z dziejów stosunków polsko-rumuńskich, red. A. Smoliński, Toruń 2017, s. $11-23$.

${ }^{7}$ D. Milewski, Wydatki hetmanów koronnych na początku lat 50. XVII wieku na podstawie akt skarbowo-wojskowych z AGAD w Warszawie, „Echa Przeszłości” (w druku).

${ }^{8}$ K. Bobiatyński, Vydatki Mihala Kazimira Radzivila na abaronu Nâsviža ǔ 1655-1660 g., „Belaruskì Gìstaryčny Aglâd” 2011, t. 18, z. 1-2 (34-35), s. 51-67.

9 Oba dokumenty, zawierające wydatki Paca z lat 1663-1667 i 1667-1670, zachowały się do dzisiaj w licznych kopiach: Archiwum Główne Akt Dawnych w Warszawie, Archiwum Radziwiłłów (dalej AGAD, AR), dz. II, księga 22, s. 625-635, Biblioteka 
Jak zaznaczył sam Michał Kazimierz Radziwiłł, pierwszy z wydawanych poniżej dokumentów zawiera wydatki poniesione przez niego na cele wojskowe od objęcia buławy polnej litewskiej. Należy od razu zwrócić uwagę, iż w zestawieniu tym szereg pozycji policzono ryczałtem za okres pełnych pięciu lat. Niewątpliwie książę dokonał tutaj pewnej manipulacji, gdyż w momencie sporządzania tego wykazu sprawował on ten urząd krócej - interesujący nas dokument został przedstawiony podskarbiemu w czerwcu 1673 roku, natomiast przywilej Radziwiłła na hetmaństwo nosi datę 15 września 1668 roku. Oczywiście trzeba też pamiętać, iż w rzeczywistości został on sfałszowany i powstał zapewne pod koniec tego roku, a ostateczną akceptację swojej nominacji książę uzyskał dopiero po elekcji Michała Korybuta Wiśniowieckiego ${ }^{10}$. Z drugiej strony, przy kilku wydatkach hetman zaznaczał, iż faktycznie poniósł na ten cel większe koszty, ale z części swoich roszczeń rezygnuje, co miało zapewne zademonstrować jego poświęcenie na rzecz ojczyzny i troskę o jak zwykle nienajlepszy stan litewskich finansów państwowych.

Jak wynika z tego dokumentu, w latach 1668-1673 niemal wszystkie wydatki wojskowe Radziwiłł musiał opłacać z własnej kieszeni. Nie jest to żadne zaskoczenie, jeśli weźmiemy pod uwagę, iż książę, jako bardzo nieudolny zresztą przywódca litewskich malkontentów, niemal przez cały okres panowania Wiśniowieckiego znajdował się w ostrym konflikcie z obozem regalistów. Popierające monarchę stronnictwo pacowskie zdominowało w tym czasie niemal wszystkie sfery życia publicznego w Wielkim Księstwie, kontrolując zarówno sytuację w wojsku, jak i funkcjonowanie większości instytucji samorządu szlacheckiego ${ }^{11}$. Do fakcji tej należał także podskarbi wielki Hieronim Kryszpin Kirszensztein, co - jak się wydaje zapewne miało wpływ na możliwości uzyskania przez Radziwiłła zwrotu

Książąt Czartoryskich w Krakowie (dalej BCzart.), rkps 162, nr 71, s. 337-345, rkps 167, nr 87, s. 265-272, rkps 399, nr 17, s. 123-129, rkps 404, s. 598-603.

${ }^{10}$ Szczegółowe omówienie tego zagadnienia zob. K. Bobiatyński, Michat Kazimierz Pac-wojewoda wileński, hetman wielki litewski. Dziatalnośćpolityczno-wojskowa, Warszawa 2008, s. 215-224, 231-235.

${ }^{11}$ Zob. na ten temat rozdział II (,Walka fakcyjna w Wielkim Księstwie Litewskim w latach 1669-1673”) książki K. Bobiatyńskiego, W walce o hegemonię. Rywalizacja polityczna w Wielkim Księstwie Litewskim w latach 1667-1674, Warszawa 2016, s. 79-182. 
poniesionych kosztów ze skarbu państwowego ${ }^{12}$. Sytuacja ta zmieniła się dopiero wiosną 1673 roku, po zawarciu kompromisu pomiędzy dworem a opozycją podczas obrad sejmu pacyfikacyjnego w Warszawie ${ }^{13}$.

Nic zatem dziwnego, iż większość zadeklarowanych wydatków Radziwiłła stanowią zaciągi wojskowe i utrzymanie własnych oddziałów komputowych. W sumie miało to kosztować księcia aż $113570 \mathrm{zl}$, a więc około 55\% całości jego roszczeń finansowych. Najwięcej, bo aż 78570 zł, pochłonął pięcioletni żołd i barwa dla chorągwi piechoty węgierskiej, tradycyjnej przybocznej asysty hetmanów ${ }^{14}$. Pozostałe pozycje (w sumie 35 tys. zł.) to wydatki na organizację jednostek husarii, pancernych, dragonii, rajtarii i drugiej choragwi pieszej. Możemy sądzić, iż są to jedne z nielicznych źródłowych śladów zaciągów, jakie Radziwiłł zaczął przeprowadzać - aby wzmocnić swoją bardzo słabą pozycję w armii - przed wyprawą na Ukrainę w 1671 roku. Ostatecznie jednak oddziały te prawdopodobnie nie zdążyły wejść do służby, gdyż podczas przemarszu na teatr działań wojennych

12 Wiemy, iż podczas komisji wojskowo-skarbowej w Wilnie, odbywającej się od lutego do lipca 1671 r., część zaległego żołdu otrzymały dwie choragwie jazdy hetmana polnego (kozacka i tatarska), które od dawna były w kompucie. W sumie było to zaledwie 7517 zł 3 gr. gotowizną i asygnacja na kolejne 6 tys. zł (Lietuvos valstybes istorijos archyvas w Wilnie (dalej LVIA), fondas SA, nr 4114, k. 12v, 32; zob. też M. Sawicki, Choragwie radziwittowskie w II potowie XVII wieku w świetle ksiag litewskich komisji wojskowo-skarbowych, [w:] Radziwittowie w stużbie Marsa, s. 252-253). Jak wynika z wydawanego poniżej dokumentu, Radziwiłł nie otrzymał chociażby obiecanego mu zwrotu kosztów poniesionych w trakcie obrad tej kadencji komisji. Sam hetman pisze o 15 tys. zł, natomiast w rejestrze podpisanym przez skarbnego lit. Kazimierza Montowta widnieje suma 12 tys. zł (AGAD, AR, dz. II suplement, nr 634.1; por. AGAD, AR, dz. II, nr 1578, s. 2). Natomiast za obrady komisji w sierpniu 1670 r. księciu udało się otrzymać refundację w wysokości tylko tysiąca zł.

${ }^{13}$ Należy zaznaczyć, iż ze względu na zły stan finansów litewskich hetman M.K. Pac także często długo oczekiwał na zwrot swoich wydatków wojskowych. Pomimo tego kilkakrotnie udało mu się uzyskać duże sumy ze skarbu. Wiemy, iż do 1667 r. otrzymał 101646 zł, a po 1670 r. część ze 100 tys. zł, których domagał się za nakłady poniesione na armię w latach 1667-1670. Dlatego też w 1673 r. oczekiwał zwrotu jedynie 50 tys. zł (AGAD, AR, dz. II, księga 22, s. 625-632; Volumina Legum (dalej VL), wyd. J. Ohryzko, t. 5, Sankt Petersburg 1860, s. 87-88; K. Bobiatyński, Michat Kazimierz Pac, s. 252).

${ }^{14}$ Już podczas komisji w 1671 r. zaległości wobec tej jednostki obliczano na 32728 zł za okres dwóch lat (AGAD, AR, dz. II, księga 22, s. 635-638). 
wojsko litewskie wymówiło posłuszeństwo swoim dowódcom i zostało rozpuszczone do domów ${ }^{15}$.

Kolejną bardzo ważną pozycję w omawianym zestawieniu stanowi zaległy jurgielt hetmański, w wysokości 8 tys. zł rocznie (w sumie 40 tys. zł, a więc niemal 20\% sumy całkowitej). Wynika z tego, iż również nie był on wypłacany księciu od początku sprawowania urzędu. Natomiast stosunkowo niewielkie kwoty Radziwiłł policzył sobie za różne obowiązki związane ze sprawowaniem buławy, jak poczta (10 tys. zł-4,9\%), ujmowanie wojska przed kampanią 1671 roku (15 tys. zł - 7\%), praca podczas komisji skarbowo-wojskowych (15 tys. zł - 7\%) czy też obrona kraju (starostwa krzyczewskiego przed wypadami Kozaków pozostających pod zwierzchnictwem cara Aleksego Michajłowicza - 12 tys. zł: 6\%). W sumie hetman polny pretendował do olbrzymiej, jak na możliwości skarbu litewskiego, sumy ponad 205 tys. zł.

Nie tylko bardzo słabe wpływy Radziwiłła w wojsku, lecz również ogólne uwarunkowania polityczno-militarne (w latach 1667-1672 wojska litewskie praktycznie nie prowadziły działań wojennych), a przede wszystkim znaczące różnice $\mathrm{w}$ kompetencjach urzędu hetmańskiego na Litwie w porównaniu do Korony powodują, iż struktura omawianych wydatków hetmana w dużym stopniu różni się od proporcji środków przeznaczanych na różne cele przez jego polskich odpowiedników. Należy zwrócić uwagę, iż w przebadanych rachunkach hetmanów koronnych z lat pięćdziesiątych i osiemdziesiątych XVII wieku jedną z najważniejszych pozycji zawsze stanowią kwoty wydawane na dyplomację, co jest związane z rolą ministrów wojny jako koordynatorów polskiej polityki południowo-wschodniej. Znaczącą część budżetu przeznaczano też na wywiad wojskowy, dużo mniejszą na wykup jeńców ${ }^{16}$.

15 K. Bobiatyński, W walce o hegemonię, s. 208-209.

16 W 1651 r. kontakty „zagraniczne” z Mołdawią pochłonęły 31\% budżetu M. Kalinowskiego, sprawy kozackie - 28\%, a wywiad - $12 \%$. W okresie od 20 II do 23 III 1652 r. - na dyplomację hetman wydał 45\%, a na wywiad 31\% pieniędzy. Warto zaznaczyć, iż były to również bardzo ważne pozycje w rachunkach S. Potockiego z lat 1653-1654, a na dyplomację - jeśli odliczymy udział w komisji lwowskiej w 1653 r. hetman przeznaczał niemal połowę swoich nakładów na wojsko (D. Milewski, Wydatki hetmanów koronnych). Natomiast struktura wydatków S. Jabłonowskiego w latach 1685- 
Trzeba w tym miejscu zaznaczyć, iż specyfikę litewską potwierdzają również rachunki wojskowe Michała Kazimierza Paca z lat 1667-1670, które z pewnością pokazują jeszcze dokładniej - niż zestawienie wydatków Radziwiłła - finansowe aspekty funkcjonowania urzędu hetmańskiego w Wielkim Księstwie. Jedyne uwzględnione w nich wydatki „dyplomatyczne" to koszty utrzymania poselstw (albo też gońców) moskiewskich i kozackich jadących przez Litwę na dwór królewski, jak również roty piechoty stanowiącej asystę komisarzy polsko-litewskich podczas rokowań dyplomatycznych z Moskwą. W sumie stanowią one tylko 6,5\% całości nakładów poniesionych w tym okresie przez Paca. Litewskie wydatki na szpiegów również można uznać za stosunkowo niewielkie. Są one jednak niełatwe do oszacowania, ponieważ „ukryto” je wśród kosztów utrzymania pogranicznych twierdz - Dyneburga (głównie wywiad na Inflanty szwedzkie) oraz Mohylewa (kierunek moskiewski) ${ }^{17}$.

Drugi z wydawanych rachunków wojskowych Michała Kazimierza Radziwiłła obejmuje znacznie krótszy okres. Hetman polny zawarł w nim swoje wydatki wyłącznie z okresu kampanii przeciwko wojskom tureckim Ibrahima Szejtana paszy jesienią 1676 roku. Należy od razu zaznaczyć, że w tym roku książę nie wziął udziału, tak jak w poprzednich latach, w głównych działaniach militarnych - obronie warownego obozu pod Żórawnem $\left(25\right.$ września - 14 października) ${ }^{18}$. Radziwiłł celowo opóźnił swój przy-

-1689 przedstawiała się następująco - misje dyplomatyczne 18\%, Kozacy zaporoscy 17\%, kancelaria hetmańska 17\%, wywiad wojskowy 33\%, pozostałe wydatki 15\% (M. Wagner, Wydatki wojskowe, s. 228).

${ }_{17} \mathrm{~W}$ sumie koszty te (także utrzymanie garnizonu, artylerii, remonty umocnień, ale bez prowiantu dla załogi Dyneburga, stanowiącego odrębną pozycję w zestawieniu) wynosiły 26334 zł (około 15\% całości wydatków Paca). Jeśli chodzi o dane szczegółowe, naczelny dowódca armii litewskiej zaznaczył jedynie, iż „na jednego szpiega duchownego religii greckiej” wydał ponad 3 tys. zł. (AGAD, AR, dz. II, księga 22, s. 632-635).

18 Szerzej na temat kampanii 1676 r. Z. Hundert, Husaria koronna w wojnie polsko-tureckiej 1672-1676, Oświęcim 2012, s. 397-415; W. Majewski, Wojny polsko-tureckie 1672-1699, [w:] Polskie tradycje wojskowe, t. 1: Tradycje walk obronnych z najazdami Niemców, Krzyżaków, Szwedów, Turków i Tatarów, red. J. Sikorski, Warszawa 1990, s. 401-409; M. Wagner, Wojna polsko-turecka w latach 1672-1676, Zabrze 2009, t. 2, s. 236-287; J. Woliński, Żórawno, [w:] idem, Z dziejów wojen polsko-tureckich, Warszawa 1983, s. 163-181. 
jazd do boku Sobieskiego, a powodów takiej decyzji trzeba szukać przede wszystkim we względach natury ambicjonalnej. Książę nie zamierzał uznać naczelnej komendy Michała Kazimierza Paca, który - po zawarciu kompromisu z Janem III podczas obrad ostatniego sejmu - tym razem stanął na czele armii litewskiej do walki z nieprzyjacielem. Dodajmy na marginesie, iż takie postępowanie szwagra spotkało się z jednoznacznie negatywną oceną króla, który w tym okresie stopniowo przestawał widzieć w Radziwille przywódcę litewskiego stronnictwa regalistów, w konfrontacji z Pacami stawiając coraz bardziej na Sapiehów ${ }^{19}$.

Podczas działań militarnych w 1676 roku Radziwiłł zajmował się organizacją drugiego rzutu sił polsko-litewskich we Lwowie. W mieście tym hetman polny pojawił się bardzo późno, bo dopiero 9 października w godzinach porannych ${ }^{20}$, a na miejscu zastał stosunkowo nieliczne grono oficerów i zaledwie około 2 tys. żołnierzy z 13 działami. Należy zaznaczyć, że książę od razu energicznie przystąpił do organizacji odsieczy, obejmując dowództwo nad napływającymi do Lwowa oddziałami i zgodnie współpracując z przebywającymi na miejscu dygnitarzami koronnymi - wojewodą sieradzkim Feliksem Potockim, wojewodą chełmińskim Janem Gnińskim oraz pisarzem polnym kor. Stefanem Stanisławem Czarnieckim. Ostatecznie Radziwiłł nie wypełnił jednak postawionego przed nim zadania, ponieważ nie zdążył dotrzeć pod Żórawno przed 17 października, kiedy to podpisano zawieszenie broni ${ }^{21}$.

Dokument ten zawiera szczegółowy rejestr wydatków na bieżące potrzeby wojenne, które hetman poniósł w trakcie trwającego kilkanaście dni

19 K. Bobiatyński, Michat Kazimierz Radziwitt, s. 240-241; A. Rachuba, Hegemonia Sapiehów na Litwie jako przejaw skrajnej dominacji magnaterii w życiu kraju, [w:] Wtadza $i$ prestiz. Magnateria $w$ Rzeczypospolitej $w$ XVII-XVIII wieku, red. J. Urwanowicz, Białystok 2003, s. 220-221; M. Sawicki, Dom Sapieżyński 1666-1685. Droga do hegemonii w Wielkim Księstwie Litewskim, Opole 2016, s. 125-130.

${ }^{20}$ Jeszcze pięć dni wcześniej Radziwiłł przebywał w Białej na Podlasiu (AGAD, AR, dz. IV, kop. 361, s. 60).

${ }^{21}$ Zob. uniwersał D. Wiśniowieckiego, obóz pod Żórawnem 30 IX 1676, Materiaty do dziejów wojny polsko-tureckiej 1672-1676, wyd. J. Woliński, cz. 11, „Studia i Materiały do Historii Wojskowości”, 1970, t. 16, cz. 2, nr 49, s. 242-243; poza tym K. Bobiatyński, Michat Kazimierz Radziwitt, s. 240; Z. Hundert, Husaria koronna w wojnie polsko-tureckiej, s. 406-408; M. Wagner, Wojna polsko-turecka, t. 2, s. 287-291. 
pobytu we Lwowie i jego okolicach. Wykaz ten ma zupełnie inny charakter niż pierwsze zestawienie - dużo bardziej ogólne, gdyż obejmowało okres kilkuletni i opiewało na niemal pięćdziesięciokrotnie wyższą sumę. Wśród nakładów poniesionych przez Radziwiłła w październiku 1676 roku na pierwszym miejscu należy wymienić koszty poczty (utrzymywania łączności), które wyniosły ogółem 1460 zł (33\%). Gdy doliczymy do tego kwotę wydaną na przewodników (kałauzów), to odsetek ten urośnie aż do $42 \%$. Kolejne pozycje to utrzymanie i wynagrodzenie wiernych królowi Kozaków zaporoskich - w sumie 800 zł (18\%), jak również zakup niezbędnych materiałów wojennych - 780 zł (18\%). Poważne były również koszty pobytu rezydenta księcia przy boku Sobieskiego - 600 zł (14\%). Natomiast bardzo małą kwotę - zaledwie 50 zł - Radziwiłł przeznaczył na działania wywiadowcze. Może to tłumaczyć jego problemy z komunikacją z obozem żórawińskim i zdobyciem dokładniejszych informacji na temat dyslokacji i działań czambułów tatarskich. Zapewne również z tego powodu dramatycznie zakończyła się próba dotarcia do Sobieskiego wysłannika posła angielskiego, gdyż orszak ten stał się łupem ordyńców. Koszty ubezpieczenia tej misji stanowią dodatkową, niewątpliwie bardzo oryginalną pozycję w rejestrze wydatków hetmana polnego.

Warto w tym miejscu zadać sobie pytanie, jaką część swoich roszczeń finansowych Radziwiłł mógł odzyskać później ze skarbu. Oczywiście w 1673 roku sam książę, wobec ogromnych kosztów przygotowań do kampanii przeciwko wojskom tureckim, nie miał złudzeń, że uda mu się uzyskać zwrot większej sumy pieniędzy i musiał zgodzić się, aby sprawę odłożono do „decyzyjej całej Rzeczypospolitej na sejmie da Bóg przyszłym”22. Sprawą tą mógł jednak zająć się dopiero sejm koronacyjny Jana III Sobieskiego, odbywający się na początku 1676 roku, a więc niemal trzy lata po sporządzeniu pierwszego z wydawanych dokumentów. Niemniej posiadamy dowody źródłowe, iż do tego czasu hetman polny musiał otrzymywać

22 Wydaje się, iż w tym roku Radziwiłł otrzymał tylko część zaległego jurgieltu na buławę (zob. asygnację na 500 zł do H. Kryszpina Kirszenszteina, Warszawa 12 IV 1673, RNB, fond 971, AD 125, k. 158). Na temat przygotowań do wojny z Portą zob. K. Bobiatyński, W drodze pod Chocim. Litewskie przygotowania do wojny przeciwko Turkom w 1673 roku, [w:] Studia z dziejów Wielkiego Księstwa Litewskiego (XVI-XVIII wieku), red. S. Górzański i M. Nagielski, Warszawa 2014, s. 27-47. 
ze skarbu pewne środki na poczet długów. Hieronim Kryszpin Kirszensztein, sporządzając obszerne sprawozdanie ze swojej gospodarki finansowej po rezygnacji z urzędu podskarbiego (kwiecień 1676), wspomniał o uiszczeniu hetmanowi należnego jurgieltu na buławę za lata 1673-1674 (16 tys. zł), a ogółem miano mu przekazać jako spłatę części zaległości kwotę 32140 $\mathrm{zł}^{23}$.

Jak dowiadujemy się z uchwalonej podczas sejmu konstytucji, ówczesne roszczenia księcia wobec skarbu oszacowano na 183355 zł. Radziwiłł miał się zrzec pretensji do 50 tys. zł, a Rzeczpospolita zobowiązała się do wypłacenia mu 133355 zł i 20 gr., w dwóch ratach. Zarazem jednak zastrzeżono, aby na przyszłość hetmani nie wpisywali do rejestru „swoich [...] żadnych prywatnych w obozie wydatków" (co świadczy o tym, iż z pewnością dopuszczali się takich praktyk), a tego typu zestawienia były odtąd odczytywane przed całą izbą poselską ${ }^{24}$. Satysfakcję finansową Radziwiłł otrzymał dopiero w następnych latach. Jak wynika ze sprawozdania kolejnego podskarbiego Benedykta Pawła Sapiehy, złożonego na sejmie grodzieńskim 1678/1679, hetman miał w końcu doczekać się (w latach 1676-1678) przekazania w pokaźnej sumy 171504 zł. Natomiast zaległości zostały zredukowane do zaledwie tysiąca $\mathrm{z}^{25}$.

\section{TEKST ŹRÓDŁOWY}

\section{Jaśnie Oświecone Książę JM pan Michał Kazimierz Radziwiłł, pod- kanclerzy i hetman polny WKsL, stosując się do konstytucyjej sej- mu roku 1673 postanowionej ${ }^{26}$, instrumentum likwidacyjej ekspensów}

${ }^{23}$ LVIA, fondas SA, nr 3444, k. 618, 628v-629v.

${ }^{24}$ VL, t. 5, s. 211.

25 AGAD, Nabytki niedokumentowe Oddziału I, nr 36, k. 434v-436v. O problemach skarbu litewskiego ze znalezieniem środków na spłatę pierwszej raty długu (50 tys. zł.) zob. obszerny list B. Sapiehy do M.K. Radziwiłła, Olkienniki 26 IX 1676, AGAD, AR, dz. II, materiały nieuporządkowane.

${ }^{26}$ Chodzi tutaj o konstytucję sejmu pacyfikacyjnego w Warszawie, która gwarantowała obydwu hetmanom litewskim zwrot wydatków poniesionych na wojsko (zob. VL, t. 5, s. 87-88). 
swych hetmańskich przede mną podskarbim wielkim $\mathrm{WKsL}^{27}$ i przytomnymi Ich MMściami pany oficjalistami skarbowymi przez Ich MMściów panów przyjaciól swoich takowe produkował

oryginat: RNB, fond 971, AD 321/2, nr 252

Jakem został hetmanem ab anno 1668 ad annum 1673, na buławę rocznego jurgieltu, tak jako w Koronie currit wielkiemu 12 000, polnemu 8000; że tedy teraźniejsza to ratyfikowała constitutio, tedy mi należy za lat pięć po zł. 8000, co uczyni 40000 zł.

Na piechoty 100 według dekretu i determinacyjej komisyjej wileńskiej żołdu po zł. 2428 gr. 15 na ćwierć; czyni na rok zł. 9714, a za lat pięć przyjdzie zł. 48570 .

$\mathrm{Na}$ barwę piechocie co rok po zł. 6000, według tejże determinacyjej uczyni przez lat pięć $30000 \mathrm{zł}$.

Od objęcia buławy na różne poczty, dla korespondencyjej z Ich MMściami pany hetmanami i za samegoż JMści pana hetmana wielkiego $\mathrm{WKsL}^{28}$ wiadomością, abym dawał znać de progressu z Korony i o niebezpieczeństwach od Rusi i od Wołynia i umyślnych osobno posyłając; lubom wydał więcej dwudziestu tysięcy kilku przez te lat pięć, albo nie kładę, tylko pretensyjej ex respectu modernae calamitatis zł. 10000.

Za ordynansem JKMści i z wiadomością i z wolą JMści pana hetmana wielkiego WKsL, zostając pod Janowem ${ }^{29}$ z JMścią panem hetmanem i in

${ }^{27}$ Hieronim Kryszpin Kirszensztein (zm. ok. 1681) - podskarbi wielki litewski w latach 1663-1676.

${ }^{28}$ Michał Kazimierz Pac (zm. 1682) - hetman wielki litewski od 1667 r., wojewoda wileński od 1669 r. Urzędy hetmańskie w Koronie od 1668 r. pełnili: Jan Sobieski (hetman wielki) i Dymitr Wiśniowiecki (hetman polny).

${ }^{29}$ Janów - miasto na Podlasiu litewskim, położone w województwie brzeskim. 
absentia JMści także idąc z wojskiem pod Dębno ${ }^{30}$, na ujęcie i traktament lubom wydał z kilkadziesiąt tysięcy, co osobliwemi gotowem comprobare dokumentami, atoli nie kładę więcej ad refusionem, tylko zł. 15000.

Na zaciąg chorągwi in fidem publicam za JKMści rekwizycyją i komisarza zesłanego do wojska pod Janów JMści pana wojewody chełmińskiego $^{31}$, także i za wolą JMści pana wojewody wileńskiego, hetmana wielkiego WKsL, wydałem gotowych pieniędzy, majętność na to zastawiwszy, na chorągiew usarską, którąm tamże pod Janowem wziął od JMści pana marszałka upitskiego $^{32}$ i nowej kompaniej różnej zaciągnąwszy, wydałem zł. 6000.

Na pancernej erekcyją, która kompleta zostawała, bo było effective koni 160 pod nią, wydałem zł. 8000.

Na draganiej 200, z liberią i z moderunkiem, dając tam i lenungi, zł. 8000.

Na drugą chorągiew pieszą i liberią zł. $\mathbf{6 0 0 0 .}$

Na rajtarią zł. $\mathbf{7 0 0 0 .}$

Gdy Kozacy Siewierscy zajachali starostwo kryczewskie ${ }^{33}$ aż po rzekę Soż, tedy chowając 100 piechoty na zamku, którym lenungi i barwę musiałem dać, wydałem zł. 12000.

${ }^{30}$ Dębno (Dubno, Dubienka) - miasto w województwie bełskim, położone nad rzekami Bug, Wełnianka i Stryhanka. 16 X 1671 przebywająca w tym rejonie armia litewska wymówiła służbę i odmówiła dalszego marszu na Ukrainę.

31 Jan Gniński (zm. 1685) - wojewoda chełmiński w latach 1668-1681. 19 IX 1671 r. zawarł pod Janowem porozumienie z wojskiem litewskim, na mocy którego zgodziło się ono podjąć służbę na okres jednego kwartału (od 1 IX do 1 XII 1671).

${ }^{32}$ Krzysztof Białłozor (zm. 1687) - marszałek upicki w latach 1670-1678.

33 Radziwiłł otrzymał to starostwo we wrześniu 1670 r., na mocy cesji poprzedniego posesora Mikołaja Stefana Раса (Российский Государственный Архив Аревних Актов, Moskwa, fond 389, nr 136, k. 350-350v). 
$\mathrm{Na}$ komisyjach będąc, jednej komisyjej wziąłem ad rationem zł. $\mathbf{1 0 0 0}^{34}$.

$\mathrm{Na}$ drugiej komisyjej naznaczono mi dekretem komisarskim, na co jest i asygnacyja JMści pana hetmana, jako dyrektora komisyjej zł. $15 \mathbf{0 0 0}^{35}$.

Wszystkiego uczyni suma, com wydał realiter i co mi debetur, rachując na rok po zł. 41 114, za lat pięć - 205570 zł.

Którą to likwidacyją przejrzawszy nullum movendo dubium anionej aprobując, ale cum toto suo effectu do kognicyjej i decyzyjej catej Rzeczypospolitej na sejmie da Bóg przyszłym zostawując, teraz in vim ratihabitionis od Rzeczypospolitej tej likwidacyjej ad rationem już niektóre przejąwszy na się Księcia JMści do wypłacenia ze skarbu Rzeczypospolitej sumy, oryginał onej z podpisami rąk użytych eo in negotio od Księcia JMści Ich MMściów panów przyjaciół, przy sobie zostawuję, a rewersał słowo w słowo przepisany, przy podpisie ręki własnej i Ich MMściów panów oficjalistów, z pieczęcią moją wydawam.

W Wilnie 2 VI 1673

Podpisy:

[Hieronim] Kryspin Kirszenstein podskarbi wielki WKsL

Andrzej Skorobohaty skarbny WKsL, pisarz grodzki trocki ${ }^{36}$

Mikołaj Franciszek Rossochacki ciwun trocki, pisarz ziemski wileński i skarbowy WKsL $\mathrm{L}^{37}$

Dawid Stanisław Ambrożewic, pisarz WKsL skarbowy, JKMści sekretarz ${ }^{38}$

34 Zapewne mowa tutaj o kadencji komisji skarbowo-wojskowej, odbywającej się w Wilnie w drugiej połowie sierpnia $1670 \mathrm{r}$.

${ }^{35}$ Chodzi tutaj o kolejną kadencję komisji, której obrady odbywały się od lutego do lipca $1671 \mathrm{r}$.

${ }^{36}$ Andrzej Kazimierz Skorobohaty (zm. 1689) - skarbny litewski od 1673 r., pisarz grodzki trocki w latach 1670-1685.

${ }^{37}$ Mikołaj Franciszek Rossochacki (zm. 1685) - pisarz skarbowy (rozchodowy) litewski od 1658 r., ciwun trocki od 1670 r., pisarz ziemski wileński od 1667 r.

${ }^{38}$ Dawid Stanisław Ambrożewicz (zm. ok. 1702) - sekretarz i dworzanin królewski, pisarz skarbowy (przychodowy) litewski od $1666 \mathrm{r}$. 


\section{Likwidacyja Księcia JMści pana podkanclerzego i hetmana polnego WKsL o ekspensa pode Lwowem kampaniej przeszłej w roku 1676}

\section{oryginat: RNB, fond 971, AD 125, k. 179-180}

Przyjechawszy Książę JM do Lwowa i za ordynansem JKMści odebrawszy koronne i WKsL chorągwie pod swą władzę, przez wszystek czas rozsyłając z ordynansami, tak z drogi, jako i spode Lwowa, na Wołyń, na Polesie Koronne, do Wielkiej i Małej Polskiej, ku Wielkiemu Księstwu Litewskiemu i do Prus, gdzie jeno o chorągwiach i regimentach słyszeć się mogło, osobliwie przeciwko zbliżającym się chorągwiom, także przeciwko Kozakom Zaporoskim z panem Hoholem $^{39}$ i inszemi idącym, co dzień częste wysyłając ordynanse, jako też do województw i powiatów pobliższych, z uniwersałami, z przestrogą i względem gromadzenia się, nie tylko Kozaków, rajtarów, ale i towarzystwo. Więc do Królowej JejMści ${ }^{40}$, do trybunału koronnego, do Księcia JMści Arcybiskupa ${ }^{41}$, wydano na to najmniej zł 1100.

Na kałauzów, którzy się do Króla JMści po dwóch, po trzech co dzień osobnemi szlakami wysyłali, żeby się z odwagą przebrać mogli, wydano najmniej zł 400.

Na szpiegów rozsyłając na szlaki różne o Ordzie, różnemi czasy wydano zł 50.

Sporządzając różne necessaria na prędkie ruszenie się wojska do JKMści, jakoby na wszelkie impety nieprzyjacielskie repressalia być mogły, tak z ognistych kunsztów dając feierwerkom na to za wiadomością JMści pana

39 Eustachy (Ostap) Hohol (zm. 1679) - pułkownik podolski, od kwietnia 1675 r. kozacki hetman nakaźny prawobrzeżnej Ukrainy w służbie Rzeczypospolitej.

${ }^{40}$ Maria Kazimiera d'Arquien Sobieska (zm. 1716).

${ }^{41}$ Andrzej Olszowski (zm. 1677) - arcybiskup gnieźnieński od 1674 r. 
[ ] ${ }^{42 a}$, jako szweinsefedry ${ }^{43}$ i letkie na wozy szpagszrejtery ${ }^{44}$ i insze do taboru rekwizyta, także na dzidy i groty dla konnych, wydało się ad rationem dobrego dopłacenia zł $\mathbf{7 8 0}$.

Kozacy Zaporoscy Barabaszowi ${ }^{45}$ i z Turczynowskim ${ }^{46}$, gdy przyszli, a nie mieli się czym sustentować, dało się zł $\mathbf{3 0 0}$.

Gdy z trębaczem Króla JMści angielskiego ${ }^{47}$ wyprawiłem tłumacza, dla bezpieczniejszego przejazdu dałem mu kontentacyjej i na drogę talarów bitych 30, co uczyni zł $\mathbf{1 8 0}$.

42 a Brak nazwiska. Można przypuszczać, iż w tym miejscu pominięto Macieja Gosiewskiego, generała artylerii lit., obecnego również w tym czasie we Lwowie.

${ }_{3} 3$ Świnskie pióra (niem. Schweinefedern) - piki/pale z metalowymi końcami, wbijane w ziemię i osłaniające piechotę strzelczą przed atakami kawalerii.

${ }^{44}$ Kozły hiszpańskie (niem. Spanischer Reiter) - rodzaj drewnianych umocnień polowych chroniących piechotę oraz tabory przed natarciem jazdy przeciwnika.

${ }^{45}$ Tomasz Barabasz Kutyski, pułkownik kozacki w służbie Rzeczypospolitej. Jego pułk jeszcze we wrześniu 1676 r. wchodził w skład załogi Stanisławowa, która skutecznie odparła ataki wojsk Ibrahima Szejtana.

${ }^{46}$ Zapewne mowa tutaj o zaufanym słudze i dworzaninie Sobieskiego, o którym król kilkakrotnie wspominał w listach do swojej żony (Jan Sobieski. Listy do Marysieńki, wyd. L. Kukulski, Warszawa 1962, s. 426, 489).

${ }^{47}$ W 1676 r. w Rzeczypospolitej przebywał poseł króla angielskiego Karola II Laurence Hyde (zm. 1711), który ok. 25 września przybył do Lwowa. Wspomnianym trębaczem był Szkot Christmass, wysłany z listami do dowodzącego siłami tureckimi serdara Ibrahima Szejtana i chana krymskiego. Zawierały one propozycję mediacji dyplomaty angielskiego w zawarciu pokoju pomiędzy oboma stronami konfliktu. Jak już wspomniano, misja ta zakończyła się tragicznie, gdyż trębacz i jego towarzysze zostali napadnięci i zamordowani przez Tatarów, a ocalał jedynie przewodnik (zob. E.A. Mierzwa, Polska a Anglia w XVII wieku, Toruń 2003, s. 434-443). Barwnie wydarzenie to opisał służący pod komendą Sobieskiego francuski inżynier Philippe Dupont: „Hyde, nie znając się zupełnie na obyczajach Turków i Tatarów, sądził, że wystarczy wysłać herolda do obozu nieprzyjacielskiego, by uzyskać pozwolenie na przedostanie się do oblężonych. $\mathrm{Na}$ próżno próbowano go odwieść od tego zamiaru, niestosownego zwłaszcza wobec Tatarów. Wysłał on swego herolda wraz ze wspaniałą świtą sześciu Wołochów i z tłumaczem, którego dał mu książę Radziwiłł. Nieszczęśnicy zostali pochwyceni przez Tatarów, całkowicie obojętnych na wyjaśnienia herolda. Ścięto im wszystkim głowy i zaniesiono je seraskierowi, by otrzymać w zamian zwyczajową nagrodę, czyli złoty dukat za każdą głowę" 
Gdym wyprawował po kilkakroć Kozaków Zaporoskich na podjazdy i w lasy osobno dla języków i wiadomości, wyszło na nich najmniej zł $\mathbf{1 0 0}$.

Gdy chorągiew rejtarska przyprowadziła czterech Tatarów dzikich, kilkadziesiąt wyciąwszy, za Starym Siołem ${ }^{48}$, z których się pewna wzięła wiadomość z obozu Króla JMści i o nieprzyjacielskich imprezach, dałem czerwonych złotych 10, co uczyni zł 120.

Pułkownikowi kozackiemu Szudzie ${ }^{49}$, który się od Dorosza ${ }^{50}$ przedał z kilkunastu swoich i na podjazdy chodził, dałem gotowemi suknem i atłasem na zl $\mathbf{4 0 0}$.

Gdy od JKMści przyjechał pan Krogulecki ${ }^{51}$ z Tatarami, dając znać o zawartym traktacie i jednego do Królowej JejMści ekspediując, a drugiego nazad do obozu Króla JMści z przydanym ode mnie młodzieńcem, dało się im talarów bitych 60, co uczyni zł $\mathbf{3 6 0}$.

Rezydentowi, który zostawał przy Królu JMści dla wzięcia wiadomości i ordynansów ${ }^{52}$, dałem zl $\mathbf{6 0 0}$.

(Ph. Dupont, Pamiętniki historyi życia i czynów Jana III Sobieskiego, tłum. B. Spieralska, opr. D. Milewski, Warszawa 2011, s. 126).

48 Stare Sioło - majętność w województwie ruskim, położona niedaleko na południe od Lwowa, od 1674 r. własność księżnej Katarzyny Radziwiłłowej.

49 Być może Hnat Szulga, sotnik w pułku czerkaskim, następnie w 1670 r. dowódca zaciężnego pułku konnego P. Doroszenki (jako „pułkownik zaporoski konny”), w 1676 r. przeszedł na stronę Rzeczypospolitej, aby rok później zbiec na Lewobrzeże i przyjąć służbę u hetmana I. Samojłowicza. W liście do A.H. Połubińskiego z 12 X 1676 r. Radziwiłł donosił, iż: „Szulhater od Dorosza największy konfident ongi, tu przyjechał, na asekuracyją łaski jkm. i pardonu zaraz się popisał, bo 3 Turków, ile jednego agę, jadącego od wejzera z listami do Szejtan baszy, przyprowadził do mnie i tej godziny posłałem go znowu na podjazd" (Materiaty do dziejów, cz. 11, s. 250).

50 Piotr Doroszenko (zm. 1698) - hetman prawobrzeżnej Ukrainy w latach 1665-1676. W 1669 r. poddał się pod protekcję sułtana, natomiast we wrześniu 1676 r. przeszedł na służbę cara, a następnie został zmuszony do złożenia buławy.

51 Zapewne Mikołaj Krogulecki (zm. po 1706), koniuszy i dworzanin królowej Marii Kazimiery, urzędnik w dobrach Sobieskich.

${ }^{52}$ Był nim Jan Kazimierz Snarski, zaufany klient Radziwiłła. 


\section{Wydanych czyni zł 4390}

[podpis] Michał Kazimierz książę Radziwiłł Podkanclerzy Hetman Polny WKsL

Osobno JM pan Pusłowski ${ }^{53}$ zostając cały czas na komendzie nad lewym skrzydłem wojska WKsL od Polesia Koronnego i mając curam granic tamecznych, wydał de suo

zl $6000^{54}$.

[podpis] Michał Kazimierz książę Radziwiłł Podkanclerzy Hetman Polny WKsL

53 Kazimierz Michał Pusłowski (zm. 1696), w 1676 r. podstoli rzeczycki i chorąży roty husarskiej Michała Kazimierza Radziwiłła.

${ }^{54}$ Dług ten, ustalony ostatecznie na 5 tys. zł, został osobno wypłacony Pusłowskiemu. Przed początkiem sejmu w grudniu 1678 r. otrzymał on 2 tys. zł, pozostałe 3 tys. zł miało mu zostać zwrócone z wpływów z pogłównego (AGAD, Nabytki niedokumentowe Oddziału I, nr 36, k. 443). 
